Nadwa | Jurnal Pendidikan Islam

Vol. 9, Nomor 1, April 2015

\title{
Implementasi Kurikulum Muatan Lokal PAI Tingkat SMP di Kabupaten Bangka Tengah Kepulauan Bangka Belitung
}

\author{
Suparta \\ Sekolah Tinggi Agama Islam Negeri Bangka \\ Email: partasuparta23@yahoo.co.id
}

\begin{abstract}
Abstrak
Tujuan penelitian ini adalah untuk mengetahui kebijakan untuk mengatasi masalah PAI, strategi penambahan jam PAI, dan model kurikulum muatan lokal di Kabupaten Bangka Tengah. Hasil penelitian menunjukkan bahwa: Pertama, untuk mengatasi kekurangan alokasi waktu PAI yang hanya dua atau tiga jam dalam seminggu maka dibuatlah kebijakan penambahan jam diluar jam PAI. Kedua, salah satu strategi agar penambahan jam tersebut berjalan efektif, maka pemerintah Kabupaten Bangka Tengah Kepulauan Bangka Belitung membuat kebijakan pelaksanaan kurikulum muatan lokal yang berbasis PAI. Ketiga, Muatan lokal yang dilaksanakan berupa muatan lokal terstruktur berupa muatan lokal iqra' dan muatan lokal yang tidak terstruktur yaitu pembinaan shalat dhuha dan shalat berjamaah, membaca al-Qur'an, pembinaan budi pekerti dan mengadakan ceramah agama.
\end{abstract}

Kata kunci: Implementasi, Kurikulum Muatan Lokal, PAI

\begin{abstract}
The purpose of this study is to determine the policies to address the problem PAI, a strategy to overcome the schedule of PAI, and models of local curriculum (PAI) in Central Bangka Regency. The results showed that: First, to overcome the shortage of time allocation PAI that is only two or three hours a week, then the policy of adding times for extracurricular should be made. Second, one strategy in order the addition of the times to be effective, the government of Central Bangka Bangka Belitung should make a policy of the implementation of local curriculum-based PAI. Third, the local curriculum carried out is structured local curriculum for iqra' and unstructured local curriculum that contains conducting Dhuha prayer and jama'ah prayers, reading the Qur'an, coaching students' character and giving religious lectures for students.
\end{abstract}

Keywords: Implementation, Local Content Curriculum, PAI 


\section{Pendahuluan}

Kehidupan dan peradaban manusia diawal millinium ketiga ini mengalami banyak perubahan. Dalam merespon fenomena itu, berbagai pihak berpacu mengembangkan pendidikan baik dibidang ilmu-ilmu sosial, ilmu alam, ilmu pasti maupun ilmu-ilmu terapan. Namun bersamaan dengan itu muncul sejumlah krisis multidimensi ${ }^{1}$ dalam kehidupan berbangsa dan bernegara seperti krisis politik, ekonomi, sosial, hukum, budaya, etnis, golongan bahkan moral-spiritual.

Akibatnya, peranan serta efektivitas pendidikan agama di SMP Bangka Belitung (Babel) sebagai pemberi nilai spiritual terhadap siswa dipertanyakan. Dengan asumsi jika pendidikan agama telah dilakukan dengan baik maka mayoritas siswa yang beragama Islam akan memiliki prilaku yang baik pula. Kenyataannya pendidikan agama dianggap belum mampu bahkan tidak dapat membawa semua siswa menjadi lebih baik.

Setelah ditelusuri pendidikan agama menghadapi beberapa kendala antara lain, waktu yang disediakan hanya dua SKS dengan muatan materi yang begitu padat dan memang penting. Dengan kata lain tuntutan yang harus dicapai oleh pendidikan agama yang harus merubah, membina watak, karakteristik dan kepribadian siswa, tidak seimbang dengan alokasi waktu yang diberikan.

${ }^{1}$ Menurut Nurkhalis Madjid, krisis multidimensi yang dialami Indonesia lebih buruk jika dibandingkan dengan negara lain. Sebab perubahan kita dari pola masyarakat agraris kepola industrial adalah mendadak tanpa pendahuluan seperti di Barat. Sehingga saat ini bangsa Indonesia tengah mengalami perbenturan tiga gelombang sekaligus yaitu gelombang agraris, industrial dan global. Kondisi seperti ini menurut Cak Nur, menimbulkan krisis dalam masyarakat sebagai akibat perubahan mendadak tersebut dalam bentuk. Pertama, Deprivasi Relatif yaitu perasaan teringkari, tersisihkan, atau merasa tertinggal dengan negara-negara lain. Kedua, dislokasi, yaitu perasaan tidak punya tempat dalam tatanan sosial yang sedang berkembang. Ketiga, disorientasi, yaitu perasaan tidak memiliki pegangan hidup akibat yang lama selama ini tidak dapat lagi dipertahankan karena terasa tidak cocok dan kehilangan identitas. Keempat, negativisme, yaitu pandangan yang mendorong kearah negatif kepada susunan yang mapan, dengan sikap-sikap tidak percaya, curiga, bermusuhan melawan dan lain sebagainya. Jika krisis-krisis ini tidak diantisipasi dengan baik akan menciptakan lahan subur bagi gejala-gejala radikalisme, fanatisme, sektarialisme, fundamentalisme, sekularisme dan lain-lain yang serba negatif. (lihat dalam bukunya, Kaki langit Peradaban Islam, (Jakarta : Paramadina, 1977) hlm.195 
Sebenarnya memang tidak adil, menimpakan tanggung jawab atas munculnya kesenjangan antara harapan dan kenyataan itu kepada pendidikan agama Islam atau guru PAI. Sebab, pendidikan agama Islam bukanlah satu-satunya faktor penyebab keterpurukan moral siswa. Apalagi dalam pelaksanannya pendidikan agama Islam masih memiliki kelemahan-kelemahan yang harus terus-menerus disempurnakan ${ }^{2}$.

Adapun diantara kelemahan yang ada dalam pelaksanaan pendidikan agama Islam adalah materi pendidikan agama Islam termasuk didalamnya mengajarkan tentang ahlak, lebih berfokus pada pengayaan pengetahuan kognitif $^{3}$ dan minim dalam pembentukkan

${ }^{2}$ Adapun kelemahan-kelemahannya antara lain : Pertama, upaya merombak kerangka pikir yang dikotomis masih dilakukan secara parsial, belum secara terpadu dengan strategi yang jelas dan jitu. Kedua, pendekatan masih cenderung normatif, menyajikan norma-norma yang seringkali tanpa ilustrasi konteks sosial budaya sehingga mahasiswa kurang menghayati nilai-nilai agama sebagai nilai yang hidup dalam keseharian. Ketiga, kurikulum yang dirancang atau yang ditawarkan boleh dikatakan minimum kompetensi atau minimum informasi bagi siswa, sayangnya pihak pengajar seringkali terpaku padanya sehingga semangat untuk memperkaya kurikulum dengan pengalaman belajar yang bervariasi kurang tumbuh. Keempat, sebagai dampak yang menyertai hal tersebut pengajar kurang berupaya menggali berbagai metode yang mungkin dapat dipakai untuk pendidikan agama sehingga pelaksanaan pembelajaran cenderung monoton. Kelima, keterbatasan sarana dan prasarana sehingga pengelola cenderung seadanya. Pendidikan agama dikalim sebagai aspek yang penting sering kali dalam urusan fasilitas memperoleh prioritas yang paling belakang. (lihat Siti Malikah Thawaf, pendekatan kontekstual bagi pendidikan agama Islam di SMP Babel, (Logos Wacana Ilmu, 1999), hlm. 164-165.

${ }^{3}$ Menurut Bloom dalam domain cognitive dapat dirinci sebagai berikut : knowledge, comprehension, aplication, analisys, syntesis dan evaluation (dalam Taxonomy of educational Objectives, Handbook I : cognitive domain, (New York: Longman, 1956). Sementara untuk pembelajaran agama harus lebih menekankan pada aspek afektif. Sebab dalam pendidikan agama Islam yang lebih diutamakan adalah mengembang EQ dan SQ peserta didik bukan IQ. Sebab dalam EQ menurut Patricia Patton, meliputi karakteristik manusia seperti, Self awareness, mood management (tahan uji, sabar dan sebagainya, self-motivation, impulse control dan people skills (lihat dalam Emotional Intellegent In The Workplace : Bridging The Gap Between What We Know And What We Do, (Singapore : SNP publishing Pte Ltd, 1977). Sedangkan dalam SQ menurut Ary Ginanjar meliputi penghambaan diri pada Tuhan, kepedulian sosial yang dapat menjadikan manusia menjadi berkarakter baik secara sosial dan spiritual. 
sikap (afektif) ${ }^{4}$ serta pembiasaan (psikomotorik) ${ }^{5}$. Kendala lain adalah kurangnya keikutsertaan guru lain dalam memberi motivasi kepada peserta didik untuk mempraktekkan nilai-nilai pendidikan agama dalam kehidupan sehari-hari ${ }^{6}$. Selain itu lemahnya sumber daya guru PAI dalam pengembangan pendekatan dan metode yang lebih variatif, minimnya berbagai sarana pelatihan dan pengembangan serta rendahnya peran serta orang tua siswa.

Pembelajaran suatu bahan ajar dalam kurikulum berbasis kompetensi tidak diorientasikan pada pencapaian target materi, melainkan kompetensi apa yang dapat dicapai peserta didik. Dengan standar kompetensi yang telah dirumuskan, maka kemampuan peserta didik dalam mempelajari suatu bahan ajar baik pada aspek pengetahuan, sikap maupun prilaku menunjukkan tingkatan yang jelas. Dengan komptetensi dasar dan indikator keberhasilan belajar, maka hasil belajar PAI akan lebih mudah diukur.

Berdasarkan kurikulum berbasis kompetensi ini diharapkan pendidikan agama Islam mampu menjawab yang selama ini belum terjawab dan mampu memberikan harapan nyata yang selama ini hanya menjadi impian. Dengan kata lain harapan besar yang harus dicapai oleh pendidikan agama Islam adalah mencetak manusia Indonesia yang anggun secara moral-spiritual akan tetapi tangguh juga di bidang intelektual.

Pendidikan agama Islam sebagai mata pelajaran (subject matter) pada jalur pendidikan formal merupakan kenyataan sejarah

${ }^{4}$ Menurut Krathwohl, afektif itu dapat dirinci sebagai berikut : minat (interest), sikap (attitude), nilai (value), apresiasi (apresiation), dan penyesuaian (Adjusment) . (lihat dalam Taxonomy of Educational Objektive, Hand Book II, domain afektif, (New York : Longman, 1980), h1m. 24-30.

5 Dalam aspek psikomotorik pembelajaran agama harus dilakukan dengan praktek langsung yang dikaitkan dengan permasalahan nyata seharihari terhadap berbagai amalan ajaran dan nilai-nilai agama. Hal ini dapat ditempuh dengan berbagai simulasi, atau modelling. (dalam Suyanta, pembelajaran pendidikan agama Islam di SMP Babel, (Jakarta, Logos Wacana Ilmu, 1999), hlm. 153.

6 Menurut Suyanto pendekatan semacam itu disebut dengan values clarification yaitu suatu pendekatan yang menekankan pada upaya untuk membantu orang mengklarifikasikan nilai-nilai yang ada pada diri sendiri dengan cara melakukan refleksi secara total terhadap nilai-nilai yang ada pada diri mereka sendiri dan juga pada nilai-nilai yang ada dalam masyarakat secara keseluruhan. (lihat dalam Refleksi Dan Reformasi Pendidikan Di Indonesia Memasuki Millinium Ketiga, (Yogyakarta : Adicita karya nusa, 2000), hlm. 77. 
yang penting dalam perkembangan pendidikan di Indonesia. Keberadaannya sebagai bagian dari program pendidikan nasional memiliki fungsi strategis dalam proses sosialisasi dan internalisasi nilai-nilai agama Islam, disamping berfungsi sebagai pengembangan intelektual.

Dalam klasifikasi ranah tujuan pendidikan, pendidikan agama Islam berfungsi mencerdaskan intelektual, emosional dan spiritual siswa secara simultan dan terpadu. Dengan demikian, pendidikan agama Islam mencakup pembinaan dan pengembangan seluruh aspek kehidupan (personality), sehingga dalam konteks kehidupan umat Indonesia, ia merupakan benteng moralitas bangsa dan pembimbing umat untuk berkepribadian dan berahlak mulia.

Untuk mencapai sasaran itu, pendidikan agama Islam tidak sekedar sebagai proses mengalihkan pengetahuan (transfer of knowledge) tentang agama Islam kepada peserta didik, tetapi juga sebagai internalisasi nilai-nilai agama. Sebab pendidikan agama Islam yang hanya mengajarkan pengetahuan tentang agama hanya akan menghasilkan peserta didik yang mengetahui ajaran agama Islam namun tidak mampu membentuk karakter (character bulding) dan membentuk kepribadian (personality building) peserta didik ${ }^{7}$.

Masalahnya adalah terjadi kesenjangan antara wilayah pengetahuan dan pengamalan, antara materi yang diajarkan dengan hasil yang diinginkan ${ }^{8}$. Dalam banyak kasus, pendidikan agama Islam di sekolah-sekolah belum secara signifikan menunjukan adanya kore-

${ }^{7}$ Karakter merupakan hal yang sangat mendasar dalam pembentukan kepribadian muslim yang dewasa. Adapun sifat-sifat yang dikembangkan dalam pendidikan agama Islam adalah semua sifat akhlak karimah seperti, ketaqwaan, integritas, kemerdekaan, keberanian, pengendalian diri, kejujuran, keadilan, kesabaran, kerajinan, ketekunan, kerendahan hati, kepercayaan diri dan tanggung jawab. Bandingkan dengan, J.I.G.M. Drost, S.J, sekolah mengajar atau mendidik? (Yogyakarta: Kanisius, 1998), hlm. 250.

${ }^{8}$ Secara teoritik seharusnya seseorang yang memperoleh nilai pendidikan agama Islam yang baik juga memiliki tingkat pengamalan agama Islam yang baik pula. Namun dalam kenyataannya tidak sedikit peserta didik yang mendapatkan nilai baik akan tetapi karakter atau prilakunya justru tidak baik. Dengan kata lain nilai yang baik tidak memiliki korelasi yang signifikan dengan pengamalannya sehari-hari. Karena pendidikan agam Islam yang diajarkan bukanlah pendidikan yang mengajarkan bagaimana menjadi manusia baik akan tetapi hanya diajarkan bagaimana mendapat pengetahuan agama yang baik dan mendapatkan nilai yang baik. Oreientasi bagi peserta didik bukan pengamalan akan tetapi penilaian. 
lasi yang searah antara gnosis dan praksis antara idealita dan realita $^{9}$. Pendidikan agama Islam belum mampu menunjukkan secara jelas bahwa karakter dan kepribadian peserta didik merupakan hasil (out put) pendidikan agama Islam ${ }^{10}$.

Melihat kondisi yang demikian maka sudah saatnyalah segera diadakan materi atau bahan pendidikan agama Islam tambahan yang berupa muatan lokal PAI. Dengan kata lain supaya dapat menjawab tantangan kehidupan siswa yang makin lama makin merosot moralnya ${ }^{11}$, serta supaya mampu memberikan kebutuhan gaya hidupnya yang modern ${ }^{12}$ maka pendidikan agama Islam harus meningkatkan pelayanan yang profesional dan materi yang capable.

${ }^{9}$ Mochtar Bukhori, transformasi tata nilai, dalam himpunan prasarana seminar POLRI tahun 1991, (Jakarta : Mabes POLRI, 1991), hlm.. 289. Begitu juga menurut Amin Abdullah mengatakan bahwa supaya bisa sesuai antara harapan yang dinginkan dengan bukti yang ada di lapangan maka perlu diadakan reorientasi pendidikan agama Islam dan reaktualisasi pendidikan agama Islam. Jika tidak segera diadakan reorientasi dan reaktualisasi pendidikan agama Islam maka kaum muslimin maksimal hanya akan mampu suvive di tengah persaingan global. Lihat Muhammad Amin Abdullah, Etika Tauhid Sebagai Dasar Kesatuan Epistimologis Keilmuan Umum Dan Agama Dari Paradigma Positivistik-Sekularistik Ke Arah Teoantroposentrik-Integralistik, (Yogyakarta: makalah seminar pengembangan IAIN sunan Kalijaga, 2002), hlm. 5 .

${ }^{10}$ Kalau hasil itu dilihat dari kacamata ranah kognitif maka out put-nya bisa dikatakan relatif baik. Akan tetapi keberhasilan pendidikan agama Islam secara kognitif tidak otomatis diikuti dengan pengamalan nilai-nilai ajaran Islam dalam perbuatan sehari-hari. Dengan kata lain out put pendidikan agama Islam masih memiliki kesenjangan yang cukup jauh antara wilayah kognitif dengan wilayah sikap dan prilaku beragama Islam. Seperti fenomena saat ini membuktikan banyak siswa atau mahasiswa yang tawuran, berbuat kerusuhan, mengedarkan obat-obatan terlarang, bahkan ada pula yang melakukan perjudian dan pembunuhan.

${ }^{11}$ Hal ini seperti yang dikatakan oleh bapak Hartana kepala Sekolah SMP 2 Koba, bahwa siswa saat ini dikhawatirkan lebih cenderung pada pergaulan bebas, apalagi setelah terungkapnya kasus video porno yang dilakukan oleh salah satau siswanya. Ini yang ketahuan kata beliau, mungkin saja yang tidak ketahuan masih banyak lagi. Untuk itu, beliau pun mengharapkan pendidikan agama atau pendidikan akhlak harus diterapkan disekolahnya. (hasil wawancara pada tanggal 14 Februari 2013 jam 14.30, di ruang Kepala Sekolah SMP 2 Koba, Bangka Tengah)

${ }^{12}$ Menurut Mastuhu karakteristik masyarakat modern yang baik adalah : pertama, terbuka dan bersedia menerima hal-hal baru dari inovasi dan perubahan. Kedua, berorientasi demokratis dan mampu memiliki pendapat yang berbeda dari lingkungannya sendiri. Ketiga, berpijak pada kenyataan, menghargai waktu, konsisten dan sistematik dalam setiap urusan. Keempat, selalu 
Untuk itu, pendidikan agam Islam harus mampu menjadi mata pelajaran yang fungsional. Agar pendidikan agama Islam lebih fungsional maka materi-materi yang diberikan jangan hanya materi yang bersifat normatif-indoktrinatif. Akan tetapi materi yang diberikan harus relevan dengan kebutuhan hidup peserta didik baik kebutuhan yang bersifat material, intelektual maupun spiritual.

\section{Dasar Pemikiran Kurikulum Muatan Lokal}

Indonesia merupakan negara kepualaun yang terbentang dari sabang sampai merauke. Jumlah pulau yang ada di Indonesia terdiri dari 3500 buah pulau yang di huni oleh berbagai suku bangsa dan agama. Bahkan bukan hanya beda suku dan agama saja, adat istiadat, budaya dan bahasanya pun beraneka ragam. Namun demikian perbedaan ini dibingkai menjadi satu dengan semboyan Bhineka tunggal ika, walaupun berbeda suku, bahasa, dan agama namun tetap satu yaitu berada dibawah naungan NKRI.

Adanya ribuan pulau serta beraneka ragamnya suku, bagasa dan agama tersirat makna bahwa potensi sumberdaya alam maupun sumber daya manusia sangatlah potensial. Dari sumberdaya alamnya indonesia memiliki kekayaan alam yang luar biasa baik kekayaan alam yang ada di daratan maupun lautan, baik berupa flora maupun fauna. Begitu juga dengan potensi sumber daya manusianya jika diasah dan diasuh dengan baik maka indonesia bisa menjadi negara yang adidaya dan sangat diperhitungkan oleh dunia.

Namun demikian, jika potensi besar tetapi tidak ada yang memberdayakannya maka yang terjadi bukanlah kesejahteraan maupun kedamaian, justru akan dapat menimbulkan komflik yang tanpa berkesudahan. Untuk itu, diantara pemberdayaan potensi tersebut adalah dengan cara mencari potensi-potensi lokal melalui penggalian. Sehingga kebutuhan yang diperlukan oleh masyarakat setempat dapat diakomodasi sesuai dengan yang diharapkan.

terlibat dalam perencanaan dan pengorganisasian. Kelima, mampu belajar lebih lanjut untuk menguasai lingkungan. Keenam, memiliki keyakinan bahwa semuanya dapat diperhitungkan. Ketujuh, menyadari dan menghargai harkat dan pendapat orang lain. Kedelapan, rasional dan percaya kepada kemampuan IPTEK. Kesembilan, menjunjung tinggi keadilan berdasarkan prestasi. Kontribusi dan kebutuhan. Kesepuluh, berorientasi pada produktivitas, efektivitas dan efesiensi. (lihat dalam memberdayakan pendidikan Islam, (Jakarta: PT. Logos Wacana llmu, 1999), hlm. 47. 
Adapun yang menjadi landasan yuridis dari kurikulum muatan lokal ini yaitu ${ }^{13}$ :

1). Undang-undang Republik Indonesia Nomor 22 tahun 1999 tentang Pemerintah Daerah

2). Undang-undang Republik Indonesia Nomor 20 tahun 2003 tentang Sistem Pendidikan Nasional, Bab X pasal 36 ayat (2) dan ayat (3), pasal 37 ayat (1), pasal 38 ayat (2).

3). Undang-undang Republik Indonesia Nomor 32 tahun 2004 tentang pemerintah daerah, pasal 13 ayat (1) huruf $\mathrm{f}$.

4). Peratuan pemerintah Republik Indonesia nomor 19 tahun 2005 tentang Standar Nasional Pendidikan

5). Peraturan Menteri Pendidikan Nasional nomor 22 tahun 2006 tentang standar isi untuk satuan pendidikan dasar dan menengah.

Sebelum adanya reformasi disegala bidang termasuk reformasi pendidikan, model atau sistem pendidikan di Indonesia masih menganut sistem sentralisasi pendidikan. Maksudnya semua kurikulum, materi, metode, dan evaluasi pendidikan semuanya disentralnya di pusat, daerah tidak mempunyai hak sedikitpun untuk merubah apalagi menggantinya. Namun, sejak terjadinya reformasi di Indonesia telah dikeluarkan aturan-aturan yang terkait dengan desentralisasi. Aturan-aturan yang dikeluarkan oleh pemerintah tersebut ${ }^{14}$ misalnya : undang-undang nomor 22 Tahun 1999 tentang pemerintah daerah menuntut pelaksanaan otonomi daerah dan wawasan demokrasi dalam penyelenggaraan pendidikan; PP nomor 25 tahun 2000 tentang kewenangan pemerintah dan kewenangan propinsi sebagai daerah otonomi dalam bidang pendidikan; undangundang RI nomor 20 tahun 2003 bab XIV pasal 50 ayat 5 mengaskan bahwa pemerintah kabupaten atau kota mengelola pendidikan dasar dan menengah serta satuan pendidikan yang bebrbasis pendidikan lokal; juga peratuan pemerintah RI nomor 19 tahun 2005 bab III pasal 14 ayat 1 bahwa kurikulum untuk SMP/Mts/SMPLB atau bentuk lain yang sederajat dapat memasukan pendidikan berbasis keunggulan lokal.

${ }^{13}$ Zainal Arifin, Konsep dan Model Pengembangan Kurikulum, (Bandung:Rosdakarya, 2012), hlm.207

${ }^{14}$ Iif Khairu Ahmadi dkk, Mengembangkan pendidikan berbasis keunggulan lokal dalam KTSP, (Jakarta: PT.Pustaka Prestasi karya, 2012), hlm. 8. 
Berdasarkan peraturan perundang-undangan di atas maka jelaslah bahwa sejak digulirkannya model pendidikan yang disentralisasi maka daerah memiliki hak untuk membuat, merancang atau melaksanakan kurikulum yang disesuaikan dengan kebutuhan lokal termasuk didalamnya sesuai dengan kebutuhan satuan pendidik$\mathrm{an}^{15}$. Dengan demikian setiap peserta didik yang ada dierah satu dengan daerah yang lainnya memiliki keunggulan bahkan keunikan masing-maisng sesuai dengan kurikulum muatan lokal yang ditawarkan. Bahkan dengan adanya otomi daerah ini, akan menjadi ajang kompetensi yang positif antara daerah satu dengan daerah yang lainnya.

\section{Tujuan dan Ruang Lingkup Kurikulum Muatan Lokal}

\section{Tujuan Kurikulum Muatan Lokal}

Menurut Dr. Rusman tujuan krikulum muatan lokal terbagi menjadi dua yaitu tujuan umum dan tujuan khusus. Tujuan umumnya yaitu dapat menjadi acuan bagi satuan pendidikan SD/MI/SDLB, SMP/MTs/SMPLB, SMA/MA/SMALB, dan SMK/MAK dalam pengembangan mata pelajaran Muatan Lokal yang akan dilaksanakan pada tingkat satuan pendidikan. Sedangkan tujuan khususnya yaitu agar siswa dapat mengenal dan menjadi lebih akarab dengan lingkungan alam, sosial, dan budayanya; agar siswa memiliki bekal kemampuan dan ketrampilan serta pengetahuan mengenai daerahnya yang berguna bagi dirinya maupun lingkungan masyarakat pada umumnya; agar siswa memiliki sikap dan prilaku yang selaras dengan nilai-nilai atau aturan-aturan yang berlaku didaerahnya, serta melestarikan dan mengembngkan nilai-nilai luhur budaya setempat dalam rangka menunjang pembngunan nasional ${ }^{16}$.

Lain halnya menurut Zainal Arifin, secara umum tujuan muatan lokal adalah untuk mempersiapkan peserta didik agar memiliki wawasan yang luas dan mantap tentang kondisi lingkungannya, keterampilan fungsional, sikap dan nilai-nilai, bersedia melestarikan

${ }^{15}$ Selama ini satuan pendidikan tidak memiliki kebebasan untuk merubah, menambah apalagi membuat kurikulum muatan lokal sendiri. Maka dengan adanya sistem disentralisasi dan didukung oleh peratuan perundang-undangan yang berlaku maka saat ini justru setiap daerah, setiap satuan pendidikan dituntut kreatifitasnya untuk membuat, merencanakan dan merencang kurikulum muatan lokal yang sesuai dengan kebutuhan user (peserta didik dan pengguna hasil didikan atau masyarakat).

${ }^{16}$ Dr. Rusman, Manajemen Kurikulum...,hal.404 
dan mengembangkan sumber daya alam, serta meningkatkan kualitas sosial dan budaya daerah sesuai dengan pembangunan daerah dan pembangunan nasional ${ }^{17}$.

Secara khusus tujuan lokal adalah pertama, peserta didik dapat belajar dengan lebih mudah tentang lingkungan dan budaya didaerahnya serta dapat diaplikasikan dalam kehidupan nyata. Kedua, peserta didik dapat memanfaatkan sumber pembelajaran setempat untuk kepentingan pembelajaran sekolah. Ketiga, lebih dekat dengan lingkungan, budaya dan alam sekitarnya. Keempat, dapat meningkatkan pengetahuan dan ketrampilan. Kelima, melatih peserta didik mandiri. Keenam, dapat menerapkan pengetahuan dan keterampilan yang dipelajarinya. Ketujuh, dapat memotivasi siswa agar mau melestarikan budaya dan lingkungannya ${ }^{18}$.

Sementara menurut Dakir, tujuan kurikulum muatan lokal tidak bisa terlepas dari tujuan pendidikan secara umum. Adapun yang langsung dapat dipaparkan dalam kurikulum muatan lokal atas dasar tujuan tersebut yaitu: pertama, berbudi pekerti luhur, sopan santun daerah disamping sopan santun nasional. Kedua, berkepribadian seperti memiliki jati diri atau kepribadian daerah juga nasional. Ketiga, mandiri yakni dapat memenuhi kebutuhan diri sendiri tapa mengharapkan bantuan orang lain. Keempat, memiliki keterampilan. Kelima, beretos kerja yakni cinta akan kerja, berkarya, dapat menggunakan waktu luang untuk berbuat yang berguna. Keenam, profesional dapat mengerjakan pekerjaan yang khas daerah. Ketujuh, produktif dapat bebrbuat sebagai produsen bukan konsumen. Kedelapan, sehat jasmani dan rohani. Kesembilan, cinta lingkungan. Kesepuluh, kesetiakawanan sosial, sehingga senang

${ }^{17}$ Zainal Arifin, Konsep dan Model Pengembangan Kurikulum..., hlm. 208

${ }^{18}$ Hal ini sesuai dengan tujuan muatan lokal yang dikeluarkan oleh Depdiknas (2006) yaitu agar peserta didik: pertama, mengenal dan menjadi lebih akrab dengan lingkungan alam, sosial dan budayanya. Kedua, memiliki bekal kemampuan dan keterampilan serta pengetahuan mengenai daerahnya yang berguna bagi dirinya maupun lingkungan masyarakat pada umumnya. Ketiga, memiliki sikap dan prilaku yang selaras dengan nilai-nilai/aturanaturan yang berlaku di daerahnya, serta melestarikan dan mengembangkan nilai-nilai luhur budaya setempat dalam rangka menunjang pembangunan nasional. 
gotong royong. Kesebelas, kreatif inovatif. Kedua belas, mementingkan pekerjaan yang praktis. Ketigabelas, rasa cinta budaya dan cinta tanah air ${ }^{19}$.

\section{Ruang Lingkup Kurikulum Muatan Lokal}

Berdasarkan Pusat Kurikulum Balitbang Kemdiknas tahun 2006 mengemukakan ruang lingkup muatan lokal adalah sebagai berikut:

Pertama, lingkup keadaan daerah dan kebutuhan daerah. Keadaan daerah adalah segala sesuatu yang berada di daerah tertentu yang berkaitan dengan lingkungan alam, lingkungan sosialekonomi, dan lingkungan sosial-budaya. Kebutuhan daerah adalah segala sesuatu yang diperlukan oleh masyarakat di suatu daerah khususnya untuk kelangsungan hidup dan peningkatan taraf kehidupan masyarakat tersebut yang disesuaikan dengan arah perkembangan daerah serta potensi daerah yang bersangkutan. Kebutuhan tersebut, misalnya kebutuhan untuk: a). melestarikan dan mengembangkan kebuyaan daerah; b). meningkatkan keterampilan dan kemampuan dibidang tertentu sesuai dengan keadaan perekonomian daerah; c). meningkatkan kemampuan bahasa asing untuk keperluan sehari-hari, dan menunjang pemberdayaan individu dalam melakukan belajar lebih lanjut (belajar sepanjang hayat); d). Meningkatkan kemampuan berwiraswasta. Termasuk didalamnya yang harus dikembangkan melalui kurikulum muatan lokal ini yaitu pembentukan karakter siswa atau kepribadian siswa. Karena tiada guna jika kemampuan intelektual mumpuni jika tidak disertai dengan basis moral yang mumpuni juga.

Kedua, lingkup isi atau jenis muatan lokal dapat berupa: bahasa daerah, bahasa asing (inggris, arab, mandarin dll), kesenian daerah, keterampilan dan kerajinan daerah, adat istiadat, pengetahuan tentang berbagai hal dan ciri khas lingkungan alam sekitar, serta halhal yang dianggap urgen oleh daerah setempat ${ }^{20}$. Misalnya ; jika pembentukan karakter atau keppribadian adalah termasuk yang urgen maka muatan lokal juga bisa dirancang model kurikulum muatan lokal berbasis moral atau akhlak.

${ }^{19}$ Lihat dalam Dakir, Perencanaan dan pengembangan..., hlm.113-114.

${ }^{20}$ Lihat dalam Rusman, Manajemen Kurikulum...,hlm.405-406, dapat dilihat juga dalam bukunya Zainal Arifin, Konsep dan model pengembanghan kurikulum..., hlm. 209-210. 
3. Implementasi Kurikulum Muatan Lokal PAI Tingkat SMP di Bangka Tengah

Berdasarkan hasil kajian penulis yang diambil dari hasil wawancara dengan pihak Kementerian Pendidikan Nasional ${ }^{21}$ dan Kemenag Bangka Tengah ${ }^{22}$ serta menanyakan ke beberapa sekolah $^{23}$ bahwa kurikulum muatan lokal yang ada di sekolahsekolah khususnya tingkat SMP masih beragam. Adapun muatan lokal yang dilaksanakannya yaitu muatan lokal iqra dan muatan lokal yang tidak terstruktur berupa pembinaan karakter. Muatan lokal ini diadakan bertujuan untuk menambah alokasi waktu mata pelajaran PAI yang hanya dua jam dalam seminggu, dimana problemnya masih banyak para siswa yang belum bisa membaca alQur'an. Oleh sebab itu, atas kebijakan kepala sekolah maka muatan lokalnya berupa muatab lokal iqra'. Sedangkan muatan lokal yang belum terstruktur yaitu muatan lokal yang membahas tentang pengembangan diri atau karakter siswa.

a. Muatan Lokal Iqra'

Dasar pemikiran dari diadakannya muatan lokal iqra, dikarenakan masih banyak anak SMP yang belum bisa membaca alQur'an. Jika cara membaca dan menulis al-Qur'an dilaksanakan pada saat mata pelajaran PAI maka alokasi waktunya tidak mencukupi. Untuk itu, pelaksanaan pembinaan cara membaca dan menulis al-Qur'an beserta tajwidnya diadakan melalui kurikulum muatan lokal Iqra'. Bahkan guru yang mengajarnya pun dibedakan antara guru yang mengajar pendidikan agama Islam dengan guru yang mengajar muatan lokal iqra ${ }^{24}$.

Dalam pelaksanaannya muatan lokal iqra' dibuat secara rinci melalui silabus, dan RPP. Dalam silabus target yang akan dicapai terdiri dari tiga aspek yaitu membaca, menulis dan juga tajwidnya. Adapun isi silabus dan RPP yang dilaksanakan dalam muatan lokal iqra' ini yaitu :

${ }^{21}$ Wawancara dengan bapak Drs. Herwan, Sekretaris Dinas Pendidikan Nasional Bangka Tengah, 14 Februari 2013 jam 10.00 WIB.

${ }^{22}$ Wawancara dengan Bapak Drs. Sulaiman, Kasi Mapenda Kemenag Kabupaten Bangka Tengah, tanggal 14 Februari 2013, jam 11.30 WIB.

${ }^{23}$ Wawancara dengan kepala sekolah SMP I Koba bapak Drs.Sigid, Bangka Tengah pada tanggal 14 Februari 2013 jam 12.30 serta wawancara dengan Kepala Sekolah SMP 2 Koba bapak Drs.Hartana, pada tanggal 14 Februari 2013 jam 14.30.

${ }^{24}$ Wawancara dengan Ibu Sofalatifah, S.Ag, pada tanggal 5 Februari 2013 pada jam 10.00 WIB. 


\section{1) Silabus Iqra Kelas VII}

Kompetensi dasar meliputi: menjelaskan macam-macam hukum bacaan nun sukun atau tanwin; memahami hukum bacaan nun sukun atau tanwin; membedakan macam-macam hukum bacaan nun sukun atau tanwin; mencari comtoh-contoh hukum bacaan nun sukun atau tanwin; menerapkan hukum-hukum bacaan nun sukun atau tanwin; membaca dan menghafalkan surat al-Humazah dengan baik dan benar; membaca al-Qur'an surat al-Baqarah juz; menulis ayat al-Qur'an surat al-Humazah; menjelaskan macam-macam hukum bacaan mim sukun dan ghunnah; memahami hukum-hukum bacaan mim sukun dan ghunnah; membedakan macam-macam hukum bacaan mim sukun; mencari contoh-contoh hukum bacaan mim sukun dan ghunnah; menerapkan hukum-hukum bacaan mim sukun dan ghunnah. Materi Pokok meiputi : menjelaskan tajwid tentang hukum tanwin dan nun mati; membaca dan menulis surat al-Humazah; menjelaskan hukum gunnah dan mim mati; membaca dan menulis surat al-Baqarah ayat 1-5. Sedangkan kilai Karakter meliputi : religius; rasa ingin tahu;gemar membaca; mandiri; kreatif; percaya diri; inovatif; menghargai prestasi; tanggung jawab 2). Silabus Iqra’ Kelas VIII

Kompetensi dasar meliputi: menjelaskan macam-macam hukum bacaan hal laam ta'rief; memahami hukum-hukum bacaan hal laam ta'rief; membedakan macam-macam hukum bacaan hal laam ta'rief; mencari contoh-contoh hukum bacaan hal laam ta'rief; menerapkan hukum-hukum bacaan hal laam ta'rief; membaca dan menghafalkan surat al-'Adiyat; menjelaskan pengertian hal laam tebal dan tipis; memahami hukum-hukum bacaan tebal dan tipis; membedakan hukum bacaan hal laam tebal dan tipis; mencari contoh-contoh hukum bacaan hal laam tebal dan tipis; menerapkan hukum-hukum bacaan hal laam tebal dan tipis; menjelaskan pengertian ro; memahami hukum-hukum bacaan tebal dan tipis; membedakan hukum bacaan ro; mencari contoh-contoh hukum bacaan ro; menerapkan hukum-hukum bacaan ro. Adapun materi pokok meliputi: menjelaskan hukum lam ta' rif; menjelaskan hukum tafhim dan tarqiq; menulis dan membaca surat al-'Adiyat. Sedangkan nilai karakter meliputi: religius; rasa ingin tahu; gemar membaca; mandiri; kreatif; percaya diri; inovatif; menghargai prestasi; tanggung jawab 


\section{3). Silabus Iqra' Kelas IX}

Kompetensi dasar meliputi: menjelaskan macam-macam hukum bacaan qolqolah; memahami hukum bacaan qolqolah; membedakan macam-macam hukum bacaan qolqolah; mencari comtohcontoh hukum bacaan qolqolah; menerapkan hukum-hukum bacaan qolqolah; membaca dan menghafalkan surat an-Nas sampai dengan at-Takastur dengan baik dan benar; menjelaskan macammacam hukum bacaan mad; memahami hukum-hukum bacaan mad; membedakan macam-macam hukum bacaan mad; mencari contoh-contoh hukum bacaan mad; menerapkan hukum-hukum bacaan mad. Adapun materi pokok meliputi: menjelaskan dan mempraktekkan hukum qalqalah qubra dan shugra; menghafalkan surat an-Nas sampai dengan at-Takatsur; menjelaskan dan mempraktekkan hukum mad. Sedangkan nilai karakter meliputi: religius; rasa ingin tahu; gemar gembaca; mandiri; kreatif; percaya diri; inovatif; menghargai prestasi; tanggung jawab.

4. Contoh RPP Iqra'

Standar kompetensi: menerapkan hukum bacaan hal nun sukun atau tanwin. Kompetensi dasar meliputi: menjelaskan macammacam hukum bacaan hal nun sukun atau tanwin; membedakan macam-macam hukum bacaan hal nun sukun atau tanwin. Tujuan pembelajaran meliputi : mendefinisikan pengertian macam-macam hukum bacaan hal nun sukun atau tanwin; mencari contoh-contoh bacaan hal nun sukun atau tanwin; membedakan macam-macam hukum bacaan hal nun sukun atau tanwin; menerapkan hukum bacaan hal nun sukun atau tanwin pada ayat-ayat al-Qur'an dengan baik dan benar. Materi pembelajaran meliputi: hukum bacaan hal nun sukun atau tanwin. Metode pembelajaran meliputi : diskusi; drill (latihan); demonstrasi (peragaan); resitensi (penugasan). Sedangkan langkah-langkah kegiatan sebagai berikut :

\begin{tabular}{lll}
\hline \multicolumn{1}{c}{ Kegiatan } & \multicolumn{1}{c}{$\begin{array}{c}\text { Standar } \\
\text { proses }\end{array}$} & \multicolumn{1}{c}{ Nilai-nilai } \\
\hline $\begin{array}{l}\text { Kegiatan Pendahuluan } \\
\text { a. Meminta siswa untuk } \\
\text { menyiapkan Al-Qur'an dan }\end{array}$ & Eksplorasi & Relegius \\
$\quad$ buku-buku tajwid & & $\begin{array}{l}\text { Rasa ingin tahu } \\
\text { Gemar membaca }\end{array}$ \\
b. Guru mengingatkan siswa & & Mandiri \\
kembali tentang pelajaran yang & & Kreatif \\
& & Percaya diri \\
\hline
\end{tabular}




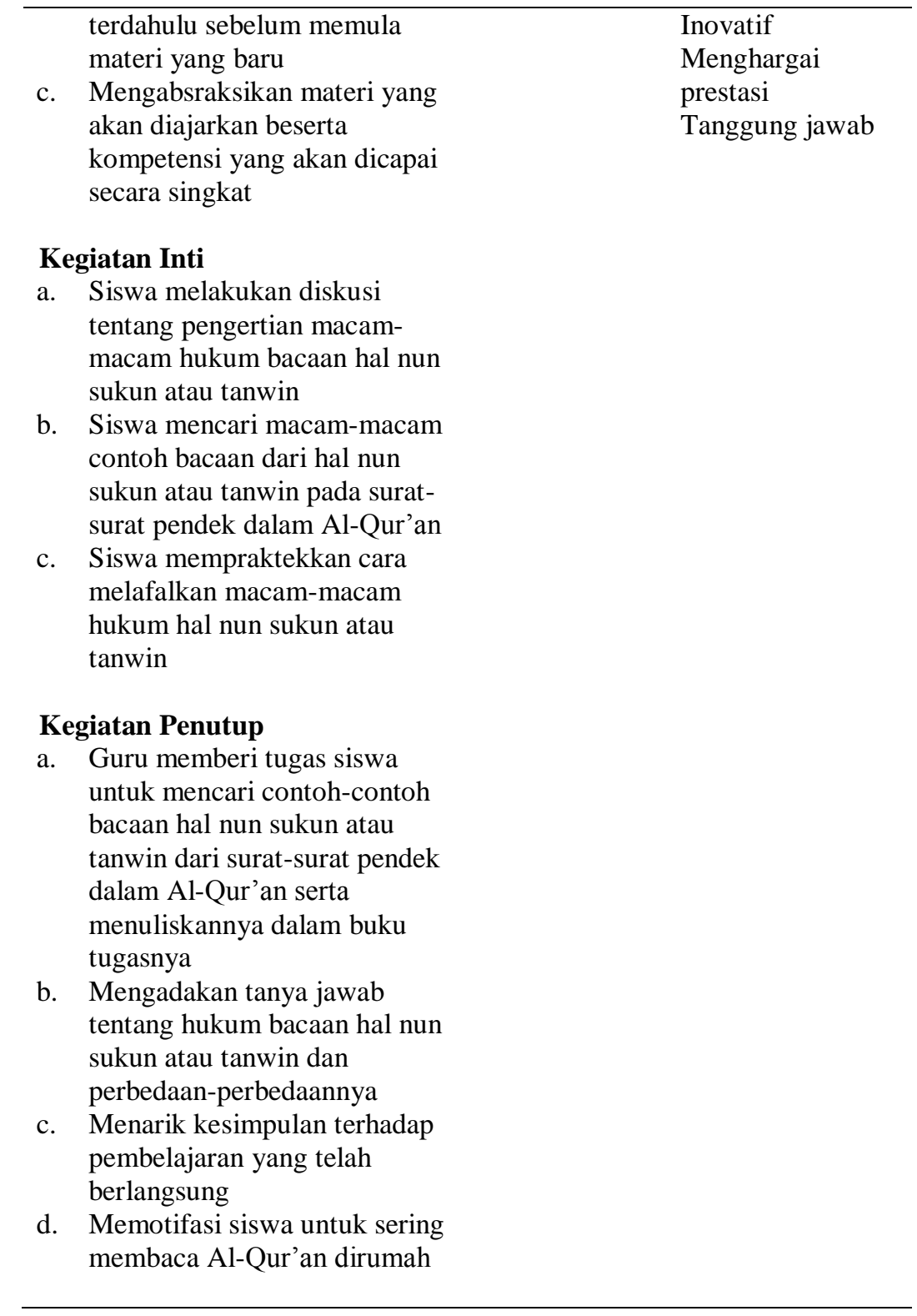

Sumber belajar meliputi: al-Qur'an dan terjemahnya; ilmu tajwid lengkap

b. Muatan Lokal PAI tidak Terstruktur

Muatan lokal ini diadakan untuk mengatasi alokasi waktu PAI yang hanya dua jam dalam seminggu. Menurut kepala sekolah SMP 
I Koba, Kabupaten Bangka Tengah Drs. Hartana, saat ini di sekolahnya sedang digalakkan pembinaan moral ${ }^{25}$. Awalnya, pembinaan moral ini akan diserahkan kepada guru agama langsung, namun karena waktu mata pelajaran PAI yang sangat sempit maka pembinaan moral diambil di luar jam pelajaran PAI. Dengan demikian tanggung jawab pembinaan moral atau karakter siswa menjadi tanggung jawab bersama baik guru agama maupun guru-guru yang lainnya.

Menurut Komal, S.Ag, pembinaan moral ini memang tidak bisa jika hanya dibebankan kepada guru agama saja, karena masalah moral atau akhlak bukan hanya tanggung jawab guru agama akan tetapi tanggung jawab bersama, baik guru di sekolah, orang tua maupun lingkungan. Sebaik apapun pembinaan moral di sekolah jika guru yang lain, orang tua dan juga lingkungan tidak mendukung maka para siswa tetap akan terpengaruh oleh hal-hal negatif. Untuk itu, harus ada kerjasama atau pengawasan bersama terhadap prilaku siswa $^{26}$.

Muatan lokal PAI yang dilaksanakan di SMPN 2 Koba belum terstruktur atau belum dibuat kurikulumnya. Hal ini disebabkan kurangnya SDM atau pengetahuan tentang cara menyusun kurikulum yang bernuansa Islami atau akhlak ${ }^{27}$. Adapun model pembinaan kepribadian atau moral yang selama ini dilaksanakan di SMP 2 Koba yaitu :

${ }^{25}$ Wawancara dengan Drs.Hartana, pada tanggal 13 Februari 2013 di ruang Kepala Sekolah SMPN 2 Koba, Bangka Tengah.

${ }^{26}$ Wawancara dengan Komal, S.Ag, Guru Agama SMPN 2 Koba pada tanggal 13 Februari jam 14.00 di Ruang Guru SMPN 2 Koba, Kabupaten Bangka Tengah.

${ }^{27}$ Hal ini terbukti, ketika peneliti mewawancarai Drs.Hartana sebagai kepala sekolah SMPN 2 Koba, pada tanggal 13 Februari 2013 jam 14.30. Beliau mengatakan bahwa, sejak beliau memimpin sudah berusaha agar para siswa di sekolahnya memiliki kepribadian yang baik, sopan santun dalam bertutur kata, berprilaku selalu sesuai dengan tuntunan agama serta memiliki akhlakulkarimah. Namun kenyataannya ada siswa berprilaku yang sangat tidak bermoral, sehingga bukan saja membuat malu almamater sekolah akan tetapi juga memalukan dunia pendidikan di Bangka Tengah dan Bangka Belitung. Adapun perbuatan amoral siswa tersebut yaitu melakukan hubungan layaknya suami isteri yang diabadikan lewat video. Bahkan menurut pengakuannya hal ini dilakukan bukan hanya sekali tapi sudah berulang kali. Hal inilah yang akhirnya menjadi berita heboh se-Babel baik berita lewat media cetak maupun elektronik (internet). Untuk itulah, Bupati Bangka Tengah akhirnya menggintruksikan kepada Dinas pendidikan agar lebih serius 


\section{1). Pembinaan Budi Pekerti atau Kepribadian}

Pembinaan budi pekerti atau kepribadian ini dilaksanakan oleh seluruh guru mata pelajaran. Setiap guru dianjurkan membina, membimbing serta membiasakan kepada para siswa agar melakukan perbuatan yang baik. Diantara kebiasaan itu terwujud dengan cara diawali dengan konsep tiga $S$ yaitu senyum, sapa dan salam. Tiga $S$ ini dilaksanakan sebelum para siswa masuk ke dalam kelasnya masing-masing. Adapun tujuan utama dari konsep ini adalah membiasakan para siswa agar memiliki rasa hormat, rasa sopan santun serta rasa tengagang rasa baik terhadap guru maupun kepada sesama kawannya sendiri. Melalui program ini diharapkan akan tumbuh rasa kekeluargaan dan rasa persaudaraan didalam lingkungan sekolah ${ }^{28}$.

Selain dibiasakan melaksanakan program tiga $S$, kebiasaan untuk menumbuhkan rasa keimanan pun selalu dilakukan dengan cara membaca do'a bersama dulu sebelum dan sesudah belajar. Hal ini memberikan pelajaran kepada siswa bahwa siswa tidak akan memiliki daya dan upaya apalagi kemampuan dalam belajar kita kecuali mendapat ridha dari Allah SWT ${ }^{29}$. Untuk itu, setiap belajar

lagi mengadakan pembinaan moral di sekolah dengan cara membuat kebijakan seluruh sekolah tingkat SMP dan SMA sederajat harus masuk jam tujuh dan pulang jam 4 sore selama lima hari, sabtu minggunya libur. Namun demikian, sampai saat ini belum ada model kurikulum muatan lokal yang pasti untuk mengisi tentang pembinaan moral tersebut. Beliau mengatakan jika ada yang membuat atau menyusun kurikulum yang berbasis akhlak maka beliau sangatlah setuju. Hal ini sesuai dengan pernyataan sekretaris Diknas Koba Drs.Herwan, dan Kasi Keagamaan Erkandi, S.Ag serta Kasi Bimas Islam Syukri, S.Ag jika ada konsep atau model kurikulum muatan lokal berbasis akhlak maka mereka sangat setuju jika diterapkan di sekolah-sekolah yang ada di Bangka Tengah khusunya untuk tingkat SMP dan SMA. (Wawancara pada tanggal 14 Februari 2013 jam 9.30 di Diknas dan jam 10.00 di Kemenag).

${ }^{28}$ Menurut Komal, S.Ag guru agama islam SMPN I Koba, kebiasaan ini sebenarnya dalam rangka mengamalkan firman Allah swt. dalam al-Qur'an yang menyatakan bahwa "sesungguhnya orang -orang mu'min itu bersaudara" bahkan dalam hadits Nabi pun dikatakan bahwa orang mu'min yang satu dengan yang lainnya bagaikan satu bangunan antara yang satu dengan yang lainnya saling membutuhkan. Dengan kata lain, para siswa secara tidak langsung belajar mengamalkan perintah Allah swt. dan Rasulnya. (Wawancara pada tanggal 13 Februari 2013 jam 13.30 di ruang kepala sekolah SMPN 2 Koba, kabupaten Bangka Tengah).

${ }^{29}$ Hal ini sesuai dengan firman Allah swt. yang mengatakan bahwa sesungguhnya Allah swt. berkuasa atas segala sesuatu. Dengan demikian, tiada satu makhluk-pun di dunia ini yang memiliki daya dan upaya kecuali hanya dari Allah swt. Jika sudah tertanam sifat ini, berarti para siswa ini 
harus berdo'a agar Allah SWT selalu membukakan hati dan pikiran sehingga diberikan kemudahan dalam menerima setiap pembelajaran yang dilaksanakan. Inilah rahasia mengapa harus berdo'a sebelum dan sesudah belajar, agar selalu ingat bahwa sang maha pemberi peringatan dan pembelajaran yang sejati hanyalah Allah swt. Dengan demikian para siswa akan tumbuh keimanan yang kuat, serta semakin yakin kepada keberadaan Allah swt ${ }^{30}$.

\section{2). Shalat Dhuha Bersama}

Kegiatan shalat dhuha bersama ini dilaksanakan bergiliran antar kelas yang satu dengan yang lainnya. Bergiliran dalam pelaksanaannya dikarenakan kapasitas mushala sekolah yang tidak memungkinkan jika pelaksanaannya bersamaan. Untuk itu, dibutalah jadwal perkelas yang dipimpin langsung oleh guru agama Islam. Shalat dhuha ini dilaksanakan untuk melatih siswa agar terbiasa melaksanakan shalat sunnah, serta melaksanakan sunnah Rasulullah SAW. Setelah shlat dhuha diadakan do'a bersama setelah itu salamsalaman.

3). Membaca Al-Qur'an

Setiap hari Jum'at pagi sebelum belajar maka seluruh kelas dianjurkan untuk membaca al-Qur'an bersama yang dipimpin oleh guru kelas masing-masing. Dalam pelaksanaannya terkadang menemukan kendala, jika guru yang berada dalam kelas tersebut adalam non muslim atau orang muslim akan tetapi kurang bagus dalam membaca al-Qur'annya. Untuk mengatasi kendala tersebut, maka dicari salah satu siswa yang ada dikelas tersebut yang fasih bacaannya, kemudian ia diminta memimpin membaca al-Qur'an bersama. Tujuan utama dari kebiasaan membaca al-Qur'an ini agar siswa menjadi cinta terhadap al-Qur'an, sehingga para siswa akan gemar membaca al-Qur'an baik di sekolah maupun di rumahnya masing-masing ${ }^{31}$.

diharapkan nantinya menjadi siswa yang yakin akan adanya Allah swt. dimanapun berada. Sebab, salah satu ciri orang yang sungguh-sungguh beriman dan bertaqwa adalah seseorang yang memiliki persaan takut kepada Allah swt. dimanapun ia berada.

${ }^{30}$ Hasil wawancara dengan kepala sekolah dan guru agama SMPN 2 Koba pada tanggal 13 Februari 2013

${ }^{31}$ Hasil wawancara dengan Drs. Sigid kepala sekolah SMPN I Koba pada tanggal 14 Februari 2013 jam 10.00 dan wawancara dengan Drs. Hartana kepala sekolah SMPN 2 Koba pada tanggal 13 Februari jam 14.00. 


\section{4). Mengadakan Ceramah Agama}

Untuk menambah wawasan ke-Islaman sekaligus membina mental atau moral anak, pihak sekolah pun sekali-kali mendatangkan penceramah atau da'i dari luar. Para muballigh yang dipanggil biasanya dari anggota atau pengurus MUI (Majleis Ulama Indonesia) kabupaten Bangka Tengah atau penceramah lain yang sudah dikenal dikalangan masyarakat Babel $^{32}$. Tujuan utamanya adalah memberikan siraman rohani maupun untuk menambah wawasan baik bagi anak-anak didik amaupun bagi para guru dan karyawan sekolah. Tentunya, sebelum penceramah tampil ada pesan-pesan khusus yang disampaikan agar materi yang disampaikan sesuai dengan kebutuhan atau problem yang sedang terjadi dilingkungan sekolah.

\section{Penutup}

Berdasarkan ulasan yang telah dipaparkan di atas dapat disimpulkan, Pertama, Untuk mengatasi kekurangan alokasi waktu PAI yang hanya dua atau tiga jam dalam seminggu maka dibuatlah kebijakan penambahan jam diluar jam PAI. Kedua, salah satu strategi agar penambahan jam tersebut berjalan efektif maka pemerintah Kabupaten Bangka Tengah Kepulauan Bangka Belitung membuat kebijakan pelaksanaan kurikulum muatan lokal yang berbasis PAI. Ketiga, Muatan lokal yang dilaksanakan berupa muatan lokal terstruktur berupa muatan lokal iqra' dan muatan lokal yang tidak terstruktur yaitu pembinaan shalat dhuha dan shalat berjamaah, membaca al-Qur'an, pembinaan budi pekerti dan mengadakan ceramah agama.

${ }^{32}$ Hal ini dibenarkan oleh Ketua MUI Bangka Tengah bapak KH.Hasyim Sya'roni, beliau mengatakan bahwa kadang-kadang saya diminta oleh beberapa sekolah untuk menyampaikan siraman rohani untuk anak-anak sekolah juga untuk para dewan guru. Kata beliau, sebenarnya tanpa diminta pun MUI memiliki kewajiban untuk memberikan pembinaan moral kepada para siswa. Apalagi untuk zaman sekarang, pergaulan, pengaruh lingkungan bagi anak-anak sangat mengkhawatirkan. Bahkan beliau sngat setuju jika bupati dan dinas pendidikan mewajibakan kepada tiap sekolah untuk mengadakan pembinaan moral atau akhlak diluar jam pelajaran sekolah. Saya dan yang lainnya siap datang ke sekolah-sekolah untuk memberikan pembinaan tersebut apalagi sudah ada panduan atau kurikulumnya (hasil wawancara pada tanggal 15 Februari 2013 pada jam 17.00 di rumahnya). 


\section{Kepustakaan}

Abdullah, Muhammad Amin, Etika tuhidik sebagai dasar kesatuan epistimologis keilmuan umum dan agama dari paradigma positivistik-sekularistik ke arah teoantroposentrik-integralistik, (Yogyakarta: makalah seminar pengembangan IAIN Sunan Kalijaga, 2002)

Ahmadi, lif Khairu dkk, Mengembangkan pendidikan berbasis keunggulan lokal dalam KTSP, (Jakarta: PT.Pustaka Prestasi karya, 2012)

An-Nahlawy, Abdurrahman, Pendidikan Islam di Rumah, Sekolah dan Masyarakat, penerjemah: Shihabuddin, (Jakarta : Gema Insani Press, 1996)

Arifin, Zainal, Konsep dan Model Pengembangan Kurikulum, (Bandung: Rosdakarya, 2012)

Asmani, Jamal Ma'mur, Buku Panduan Internalisasi Pendidikan Karakter di Sekolah, (Yogyakarta : DIVA press, 2011)

Azzet, Ahmad Muhaimin, Urgensi Pendidikan Karakter di Indonesia, Revitalisasi Pendidikan Karakter Terhadap Keberhasilan Belajar dan Kemajuan Bangsa, (Yogyakarta: Arruz Media, 2011)

Bloom, Taxonomy of educational objective, Hand Book II (New York : Longman, 1980)

Bukhori, Mochtar, Transformasi Tata Nilai, dalam Himpunan Prasarana Seminar POLRI Tahun 1991, (Jakarta : Mabes POLRI, 1991)

Departemen Agama RI. Al-Qur'an dan Terjemahnya, (Jakarta : Depag RI, 1971)

Hafidhuddin, Didin, Modul Tafsir Mudhu'i Program Doktor Pendidikan Islam, (Bogor : Program Pascasarjana Universitas Ibnu Khaldun, 2011)

Ibnu abdul hafidh Suwaid, Muhammad, Cara Nabi Mendidik Anak Disertai dengan Contoh-contoh Aplikatif dari Kehidupan Salafush Shaleh dan Ulama Amilin, (Jakarta : Al-I'tisham Cahaya Umat, 2010)

Ismail SM dkk, Paradigma Pendidikan Islam, (Yogyakarta: Fakultas Tarbiyah IAIN Walisongo bekerja sama dengan Pustaka Pelajar, 2001) 
J.I.G.M. Drost, S.J, Sekolah Mengajar atau Mendidik? (Yogyakarta: Kanisius, 1998)

Langgulung, Hasan, Beberapa Pemikiran Pendidikan Islam, (Bandung : PT. Al- Ma'arif, 1980)

Madjid, Nurkhalis, Kaki Langit Peradaban Islam, (Jakarta: Paramadina, 1977)

Mastuhu, Memberdayakan Pendidikan Islam, (Jakarta: PT. Logos Wacana llmu, 1999)

Miller, dalam Munir Mulkhan, Cerdas di Kelas Sekolah Kepribadian, Rangkuman Model Pengembangan Kepribadian dalam Pendidikan Berbasis Kelas, (Kreasi Wacana, 2002)

Mustopa, A, Akhlak Tasawuf, untuk Fakultas Tarbiyah, (Bandung : Pustaka Setia, 1997)

Nata, Abudin, Pendidikan Islam di Era Global, Pendidikan Multikultural, Pendidikan Multin Iman, Pendidikan Agama, Moral dan Etika, (Jakarta : UIN Jakarta Pers, 2005)

Raharjo, Dawam, Ensiklopedi Al-Quran Tafsir Sosial berdasarkan Konsep-konsep Kunci, (Jakarta: Paramadina, 1996)

Suyanto, Refleksi dan Reformasi Pendidikan di Indonesia Memasuki Millinium Ketiga, (Yogyakarta: Adicita Karya Nusa, 2000)

Thawaf, Siti Malikah, Pendekatan Kontekstual PAI, (Logos Wacana Ilmu, 1999)

Wawancara: Kepala Dinas Kementerian Pendidikan Nasional, Kepala sekolah SMPN I dan 2 Koba, Guru Agama SMPN 1 dan 2 Koba, Ketua MUI Bangka Tengah dan Ketua BAS Bangka Tengah) 